\title{
Alteration in Serum Homocysteine Levels upon Ingestion of Monosodium Glutamate (MSG) to Adult Male Rats
}

\author{
Jyoti Sharma $^{1}$, Kuldip Singh ${ }^{2}$, Pushpa Ahluwaliaa ${ }^{1}$ and Arvind Preet Kaur ${ }^{3}$ \\ ${ }^{1}$ Department of Biochemistry, Panjab University, Chandigarh, India \\ ${ }^{2}$ Department of Biochemistry, Govt. Medical College, Amritsar, Punjab, India \\ ${ }^{3}$ Department of Horticulture, Punjab Agricultural University Ludhiana, Punjab, India
}

KEYWORDS Monosodium Glutamat. Homocysteinaemia. Atherosclerosis. Atherothrombosis

\begin{abstract}
The study was conducted to evaluate the alterations in serum homocysteine levels upon ingestion of monosodium glutamate at the dose levels of $4 \mathrm{mg}$ and $8 \mathrm{mg}$ per gram body weight for consecutive 7 days. A study revealed a significant increase in serum homocysteine levels by $27.06 \%(\mathrm{p}<0.01)$ and $73.98 \%(\mathrm{p}<0.001)$ in $4 \mathrm{mg}$ monosodium glutamate per gram body weight (Group-2) and $8 \mathrm{mg}$ per gram body weight monosodium glutamate (Group-3) treated animals compared to normal animals. These observations suggested that ingestion of monosodium glutamate at dose level of $4 \mathrm{mg} / \mathrm{g}$ body weight and $8 \mathrm{mg} / \mathrm{g}$ body weight produced hyperhomocysteinemia and thereby could initiate atherothrombosis.
\end{abstract}

\section{INTRODUCTION}

Cardiovascular diseases are increasing in prevalence and represent a major public health burden of $21^{\text {st }}$ century. Adiels et al. (2008). Atherosclerosis is profoundly affected by diet and can be approached from a nutritional point of view also. Getz and Reardon (2007). The craze for Chinese, Japanese, fast food and ready served foods like 2-minute noodles, soups etc. all containing Monosodium glutamate (MSG) is increasing tremendously especially in Indian younger generation. Previously, we have reported that MSG induces hyperlipidemia, hyperglycemia and oxidative stress in blood, erythrocyte, liver and heart, a well known risk factor for atherosclerosis (Ahluwalia et al. 1996; Choudhary et al. 1996; Kuldip and Ahluwalia 2002, 2003, 2005, 2007).

According to American Heart Association, around 79.4 million people are suffering from one or more types of cardiovascular diseases like coronary heart disease (CHD), angina, high blood pressure and stroke. Dalla (2007). This epidemic has the potential to place a large social and economic burden on the developing countries like India. In 2008, Kaul reported that about 60

Corresponding author:

Dr. Kuldip Singh, Senior Lecturer,

House No: 4319, Ward No. 13, Near Punjab Tools,

G. T. Road- Bara, Sirhind Distt. Fatehgarh Sahib

Punjab, India

Mobile: 09417355095

E-mail: drkuldip08@gmail.com million people in India are suffering from blockages of coronary artery, which is an alarming data. Recently, this situation warrants the need to understand new risk factors responsible for this problem. New emerging independent risk factors of cardiovascular diseases (CVD) include elevated level of homocysteine in serum (Yusuf et al. 2004; Humphrey et al. 2008). Altered homocysteine metabolism is implicated as a pathogenic factor in atherosclerosis, may be due to its export from endothelial cells, contributing to the generation of extra cellular hydroxyl radicals associated with oxidative modification of LDLcholesterol and its incorporation into macrophages, a key step for initiation of atherosclerosis. Nurk et al. (2002). So in the present work, we wanted to study the effect of oral ingestion of MSG at dose levels of 4 and $8 \mathrm{mg} / \mathrm{g}$ body weight for consecutive 7 days on the levels of serum homocysteine, reported to be altered in coronary heart disease.

\section{MATERIALS AND METHODS}

Chemicals: Monosodium glutamate was purchased from SRL (Sisco Research Laboratories Pvt. Ltd., Mumbai). All other chemicals used were of analytical grade.

Animals and Treatment: Normal adult male rat (Wistar), 140-150gm in body weight, procured from animal house, Panjab University, Chandigarh were divided into three groups of 6 rats each and MSG was given orally at dose level of 4 and $8 \mathrm{mg}$ per gram body weight for 7 consecutive days, 
using canola. Animals were maintained on a rat pellet diet (Hindustan Lever Ltd., Mumbai) and had free access to water.

Sample Preparation: Animals were fasted overnight and on $8^{\text {th }}$ day blood was drawn from the eye of rat and collected in the plain vial. The blood samples were centrifuged by using cold centrifuge machine at $4^{0} \mathrm{C}$ for 10 minutes at 3000rpm and supernatant (serum) obtained, was used for the estimation of homocysteine levels.

Biochemical Assay

Homocysteine Assay: Homocysteine was qualified by using reverse phase high performance liquid chromatography (HPLC - Water India Limited) and fluorescence detections by applying the method of Ueland et al. (1993). This assay was measure total homocysteine (both reduced and oxidized forms). Homocysteine was dissociated from non relevant proteins and other disulfides by reduction with sodium borohydride. The proteins was precipitated by using $0.6 \mathrm{M}$ perchloric acid. The sulfhydryl amino acids so, obtained will reacts with fluorescent reagent 7flurobenzo-2-oxa-1, 3-diazole 4-sulfonic acid reagent.

\section{Statistical Analysis}

Numerical data from study groups (4 and 8 mg MSG/g body weight treated groups) and control group (Group-1) were compared using Students " $\mathrm{t}$ " test. Values were expressed as mean values \pm standard deviation (SD). Sigma stat version 3.0 was used for statistical analysis. "P" value of less than 0.05 was considered to indicate statistical significance.

\section{RESULTS AND DISCUSSION}

Oral ingestion of MSG at dose level of $4 \mathrm{mg}$ and $8 \mathrm{mg}$ per gram body weight was found to be significantly increased the levels of homocysteine by $27.067 \%$ and $73.98 \%$ in $4 \mathrm{mg}$ MSG (from $9.57 \pm$ $1.08 \mu \mathrm{mol} / \mathrm{lit}$ to $12.16 \pm 1.26 \mu \mathrm{mol} / \mathrm{lit}$ ) and $8 \mathrm{mg} \mathrm{MSG}$ per gram body weight (from $9.57 \pm 1.08 \mu \mathrm{mol} /$ lit to $16.65 \pm 1.02 \mu \mathrm{mol} / \mathrm{lit}$ ) respectively compared to control animals (Table 1). A significant increase in homocysteine observed in MSG ingested animals could be responsible for the induction of atherothrombosis either via the formation of homocysteine thiolactone, which reacts with LDL to form LDL-homocysteine thiolactone aggregates. Theses aggregates are taken up by
Table 1: Changes in serum Homocysteine level upon ingestion of MSG at different dose levels (0, 4 and $8 \mathrm{mg} / \mathrm{g}$ body weight) for 7 consecutive days to adult male rat.

\begin{tabular}{ll}
\hline Groups & Homocysteine (mmol/litre) \\
\hline Group-1 (0 mg/g b.wt.) & $9.57 \pm 1.08^{\mathrm{a}}$ \\
Group-2 $(4 \mathrm{mg} / \mathrm{g}$ b.wt.) & $12.16 \pm 1.26^{* *}(+27.06)^{\mathrm{b}}$ \\
Group -3 $(8 \mathrm{mg} / \mathrm{g}$ b.wt) & $16.65 \pm 1.02^{* * *}(+73.981)$
\end{tabular}

a- values are expressed as mean \pm S.D of 6 observations b- Values in percentages represent change with respect to control.

$* \mathrm{p}<0.05, * * \mathrm{p}<0.01, * * * \mathrm{p}<0.001$

macrophages and subsequently incorporated into foam cells in early atherosclerotic plaques. Within these plaques homocysteine thiolactone accelerates proteins and modifies the oxidative processes of the vessel, thereby promoting atherothrombosis (McCully and Wilson 1975; Angeline et al. 2007). In addition, homocysteine contain sulfhydryl group, which undergoes oxidation to the disulfide at physiological $\mathrm{pH}$. The reaction is catalyzed by transition metals and a variety of reactive oxygen species (ROS) such as superoxide radical $\left(\mathrm{O}_{2}^{-}\right)$and hydrogen peroxide $\left(\mathrm{H}_{2} \mathrm{O}_{2}\right)$. The oxygen derived molecules may contribute oxidation of LDL and endothelial dysfunction and promote proliferation of vascular smooth muscle cells (Loscaizo 1996; Wald et al. 2002) and ultimately cause tissue damage and eventual loss.

In conclusion, the aforementioned observations suggested that ingestion of MSG at dose levels of $4 \mathrm{mg}$ and $8 \mathrm{mg}$ per gram body weight produced hyperhomocysteinemia and hence could be responsible for the initiation of atherothrombosis.

\section{ACKNOWLEDGEMENT}

The authors are grateful to the University Grants Commission (UGC) for providing financial support to conduct this work.

\section{REFERENCES}

Adiels M, Olofolofsson S, Taskinen MR, Boren J 2008. Overproduction of VLDL is the hallmark of dyslipidemia in the metabolic syndrome. Arterio Throm Vasc Biol, 28: 1225-1236.

Ahluwalia P, Tewari K, Choudhary P 1996. Studies on the effect of monosodium glutamate (MSG) on oxidative stress in erythrocytes of adult male mice. Toxicol Lett, 84: 161-165.

Dalla S 2007. Heart disease and Stroke Statistics-2007 update. American Heart Association, Texas: USA. 
Angeline T, Aruna RM, Ramadevi K, Mohan G, Jeyaraj N 2007. Homocysteine status and acute myocardial infarction among Tamilians. Ind J Clin Biochem, 20(1): 18-20.

Choudhary P, Malik VBT, Puri S, Ahluwalia P 1996. Studies on the effect of monosodium glutamate (MSG) on hepatic Microsomal lipid peroxidation, calcium, ascorbic acid and glutathione and its metabolizing enzymes in adult male mice. Toxicol Lett, 84: 161165.

Getz GS, Reardon CA 2007. Nutrition and cardiovascular disease. Am Heart Assoc, 27: 2499-2506.

Humphrey LL, Rongwei FU, Kevin R, Michele F, Mark $\mathrm{H}$ 2008. Homocysteine level and coronary heart disease incidence: A systemic review and Metaanalysis. Mayo Clin Proc, 83 (11): 1203-1212.

Kaul U 2008. World Heart Day. Indian Express, Weekly, September 27, 2008, P. 15.

Kuldip S, Ahluwalia P 2002. Studies on the effect of MSG administration on the activity of xanthine oxidase, SOD and catalase in hepatic tissue of adult male mice. Ind J Clin Biochem, 17(1): 29-33.

Kuldip S, Ahluwalia P 2003. Studies on the effect of MSG administration on some antioxidant enzymes in arterial tissue of adult male mice. J Nutr Sci Vitaminol, 49: $145-148$
Kuldip S, Ahluwalia P 2005. Alteration in some antioxidant enzymes in cardiac tissue upon MSG administration to adult male mice. Ind J Clin Biochem, 20(1): 43-46.

Kuldip S, Ahluwalia P 2007. Studies on the effect of MSG administration on glutathione and its metabolizing enzymes in cardiac tissue of adult male mice. SFRRIndia Bull, 7: 22-27.

Loscaizo J 1996. The oxidant stress of homocysteinemia (Editorial). J Clin Invest, 98(1): 5-7.

McCully KS, Wilson RB 1975. Homocysteine theory of arteriosclerosis. Arteriosclerosis, 22: 215-227.

Nurk E, Grethe ST, Stein EV, Ottar N, Helga R, Ueland PM 2002. Plasma total homocysteine and hospitalization for cardiovascular disease. Arch Intern Med, 162: 1374-1378.

Ueland PM, Refsum H, Stabler SP, Malinow MR, Aderson A, Atten RH 1993. Total homocysteine in plasma or serum- Method and clinical application. Clin Chem, 39: 1764-1779.

Wald DS, Law M, Morris JK 2002. Homocysteine and cardiovascular disease: Evidence on casulaity from a meta-analysis. Bio Med J, 325(7374): 1202.

Yusuf S, Hawken S, Ounpu S 2004. Effect of potentially modifiable risk factors associated with myocardial infarction in 52 countries (The inter heart Study): Case control study. Lancet, 364: 937-952. 